\title{
Features of Cash Flow Compared to Profit
}

\author{
KASTRATOVIĆ Edita ${ }^{13}$, KALIČANIN Milica ${ }^{14}$, \\ KALIČANIN Zoran ${ }^{15}$
}

\begin{abstract}
Taking into account modern business circumstances, it is easy to conclude that money represents the most significant and the most deficient of goods. One of the most important conditions for such a situation, among other things, is the irresponsibility of numerous business organization leaders. Due to a high degree of competitiveness and the globalization of the modern market, each business segment must be thoroughly planned. The problem of liquidity is one of the most modern issues that modern economic organizations encounter. The starting point for solving a large number of organizational-business problems are the financial statements of the organization, in the forms of a balance sheet, an income statement and a cash flow statement. The topic of this paper is the presenting of a real economic situation in which a business organization realizes, at the same time, profit but also negative cash flows. The necessary and essential roots to address this disparity are the proper planning of operations. It is necessary to apply some of the basic balance rules of financing that are reflected in the matching of fund maturity and funding sources. It is necessary to finance short-term funds exclusively from short-term sources. Otherwise, the liquidity of the organization can be seriously disrupted.
\end{abstract}

Keywords: income statement, profit, cash flow, income, expenses, maturity, effectiveness, globalization

JEL: G10

UDK: 657.422

005.52:330.143

COBISS.SR-ID 253496076

\section{Introduction}

In modern business conditions, each company has at its disposal a large number of data and reports. Some are designed to regulate legal obligations, while others are the product of management information needs used to make management decisions. The cash flow statement and the income statement represent one of the basic financial statements, the composition of which is determined by the legal provisions and the International Accounting Standards. Simply speaking, the cash flow statement represents the inflow and outflow of cash and cash equivalents. On the other hand, the income statement is a financial statement showing the income and expenses of a company in order to determine the operating results (realized profit or loss) over a specific period of time. The content of the profit and loss account, naturally, consists of revenues and expenditures, with a particular emphasis on their structure.

\footnotetext{
${ }^{13}$ Faculty for Business Economics and Entrepreneurship, Belgrade, Serbia

${ }^{14}$ Faculty of business studies and law, University Union - Nikola Tesla, Belgrade, Serbia

${ }^{15}$ Faculty of business studies and law, University Union - Nikola Tesla, Belgrade, Serbia 
Apparently, these are similar indicators, but the financial statements have largely different meanings. Taking into account the fact that the accounting principle applies in economic conditions and not the collection, there is a certain level of mismatch between the income and the inflow of money, on the one hand, as well as the expenditure and the cash outflow on the other.

\section{Income statement}

The income statement represents a two-sided review of revenue and expenditure for a specific accounting period, and most often it relates to one business year. The information that is the main product of the profit and loss account is a financial result, which may be positive or negative. A positive financial result, profit or profit arises in a situation where the sum of revenues is higher than the sum of expenditures of a business organization. A negative financial result, or loss, arises in the situation where the expenditures are higher than the revenues.

To a large extent, the calculation of the financial result exerts depends on the structure of the income and expenses that are an integral part of the income statement. Revenues and expenditures, according to their characteristics, can be as follows, according to Djukić (2005):

1. operating,

2. financial,

3. extraordinary,

4. non-operating.

Operating revenues or expenses represent the exponent of the core business of the organization. Financial, as their name implies, are the result of operations based on financial activities. Extraordinary income or expenses are based on factors that are the result of unforeseen circumstances. Non-operating income or expenses arise from additional and secondary business activities.

\section{Cash flow statement}

A cash flow statement is one of the essential financial statements that presents in detail the monetary effects derived from operating, the investment and financial activities of a business organization over a certain period of time. Cash flow information is the basis for internal and external users for issues related to the ability of businesses to generate cash.

The decisions made by the management on the basis of these reports concern the following, according to Epstein, Jermakowicz (2007):

1. liquidity,

2. profitability,

3. indebtedness.

Cash flow, in its most significant part, involves liquidity. Liquidity represents the ability of an organization to settle its obligations in accordance with the maturities. When compiling a cash flow statement, it is necessary to indicate the sources of the money (which is reflected by the inflows), and what the money was used for (represented by the outflows). In addition to the liquidity analysis, the application of cash flow is very intensive when analyzing the creditworthiness, according to Libby, Libby Daniel (2011). In this case, cash flow projections are realized, whereupon a prediction of the cash flow movement is carried out in the subsequent time periods. Also, very often, cash flow multipliers are applied when valuing the company's value. The most appropriate way to evaluate the value of the company is to discount future cash inflows and outflows, i.e. carry out an analysis of the future cash flow of the company and its reduction to the present value.

From the methodological aspect, there are two ways to create a cash flow statement, according to Delaney et al., (2003):

1. the indirect method, 
2. the direct method.

The essential difference between these methodological approaches is in the valuation of cash flow from business activities, while the indicators of financial and investment activities do not differ. The direct method is stipulated by the law and all companies in Serbia must use the said method when submitting the final accounts. However, the indirect method has a wide range of uses in practice for reasons of its simplicity and speed required for compilation. Despite such characteristics, the cash flow statement has a high degree of information power for the managerial sector when making management decisions. In order to compile a cash flow statement based on a direct method, it is necessary to dispose with the following data, according to Đukić (2005):

1. two successive balance sheets (for the end and the beginning of the observed period),

2. an income statement for the accounting period,

3. other significant data which can be obtained from the main accounts of the organization.

Applying this method involves adjusting the positions of the profit and loss account to the changes that have occurred on individual balance sheet positions in two consecutive accounting periods in order to obtain the appropriate positions in the cash flow statement.

In using the indirect method when compiling a cash flow statement, the starting point is the net operating result, which is adjusted for the effects of non-cash transactions, i.e. for the income and expenses that do not lead to inflow and outflow in the accounting period for which this report is compiled.

Unlike the direct method by which users are informed about the inflow and outflow of cash from business activities, using the indirect method can explain why the net cash flow from business activities differs from the other measure of business performance - net profit, according to Auerbach, Devereux (2013).

\section{The correlation between profit and cash flow}

As already noted in the text, accounting records in the economy are based on invoicing. This practically means that when selling goods, finished goods or services, there are bookkeeping and income records. Most often, the sale is operatively realized and contracted with different delivery and payment terms and thus there is a certain discontinuity of flows.

When goods are shipped and invoiced, revenue and receivables are recorded in the income statement, but if payment is agreed with some future date, there is no cash flow. Only when the payment is realized is the cash flow recorded in the cash flow report. An identical movement pattern occurs when recording expenditures or cash outflow.

Both cash flow and the financial result are crucial aspects of business. The cash flow shows the movement of money, which is essential for the daily and operational management of the financial operations of the organization. In this way, information about the financial assets used for payments to suppliers, taxes, employees and the like is obtained. The financial result, specifically speaking - the profit that is the topic of this paper, reflects the general economic success of the business and represents the basis for calculating taxes. Taking into account such a constellation of relationships, the financial image of the company's business success can take on paradoxical forms, according to Kimmel, Weygandt, Kieso (2011). In case of a lack of fresh money despite a positive financial result, a company can end up in bankruptcy, in the extreme case.

An organization can continuously realize its accounting profits, but profit and money may be engaged in some other non-cash form, such as receivables. In such a situation, when the dynamics of collecting receivables and money circulation is initiated, cash flow enters into a positive segment. Profit loss, in the long run, has a negative impact on the movement of cash flow. However, what is important to note is that the flow of money can be artificially generated.

In particular, this involves loans and borrowings. In today's business conditions, money has become the most deficient of goods. Commercial banks have recognized such movements and 
offer a wide range of possible loans for resolving liquidity issues. Of course, such solutions have sound economic support only in cases of profit, or the possibility of profit in the balance sheets of the organization. In addition to cooperating with banks, the company can access fresh financial assets through a loan from a founder, through the sale of a fixed asset, or the sale of a claim with a certain discount. Such sources can contribute to the positive flows of monetary movements, but they do not constitute profit.

From all the mentioned, we can conclude that negative movements concerning cash flows have a high degree of negative impact on the business organization. One of the main factors that could influence such activities is the incorrectly designed commercial activities of the organization. Specifically, this involves inadequately arranged payment terms with customers and suppliers. Payment deadlines for suppliers are considerably shorter than the time limits for collecting receivables by customers, and such a dynamic exists with a constant deficit of cash.

Also, an inadequate inventory policy and inventory management process can lead to a large share of assets in the form of inventory and create a lack of fresh money. Drawing profits through payments to owners and founders can contribute to creating negative trends in the cash flow statement.

It is also interesting to mention the issue of the impact of depreciation costs on cash flows, as well as the correlation between profit and cash flow. One of the more important characteristics of depreciation costs is that it is a non-monetary expense. Depreciation is a gradual process of spending fixed assets. For this reason, the cost of depreciation is added to the inflow of cash from operating activities. The same is true with other non-cash expenses, such as write-offs.

Taking into account the above facts, it is possible to determine the great importance of the time determinant of creating cash flows. This results in the importance of activities related to planning in management and strategic activities related to business.

\section{Cash flow and the financial results of the Coca-Cola Company}

The influence of the Coca-Cola brand on literally the whole planet is well known, as well as the extent to which it impacts the everyday life of an enormous number of people. Table 1 shows the data from the Coca-Cola cash flow statement for 2015 and 2016.

Table 1. Cash flow of the Coca-Cola Company for 2015 and 2016. (mil. \$)

\begin{tabular}{||l|l|l||}
\hline Cash Flow & $\mathbf{2 0 1 6}$ & $\mathbf{2 0 1 5}$ \\
\hline Net income & 6.527 & 7.351 \\
\hline Depreciation & 1.787 & 1.970 \\
\hline Correction of net income & 680 & 1.349 \\
\hline Changes in other operative activities & 221 & 157 \\
\hline Cash flow from operative activities & 8.796 & 10.528 \\
\hline Capital expenditure (CAPEX) & 2.262 & 2.553 \\
\hline Investments & 1.125 & 1.752 \\
\hline Other cash flow from investment activities & 138 & 1.881 \\
\hline Cash flow from investment activities & 999 & 6.186 \\
\hline Dividends paid & 6.043 & 5.741 \\
\hline Own shares purchased & 2.247 & 2.319 \\
\hline Net loans & 1.666 & 2.696 \\
\hline Other cash flow from financial activities & 79 & 251 \\
\hline Cash flow from financial activities & 6.545 & 5.113 \\
\hline Effect of changes in foreign exchange rates & 6 & 878 \\
\hline Changes in cash and cash equivalents & 1.246 & 1.649 \\
\hline
\end{tabular}

Source: https://finance.yahoo.com/quote/KO/financials? $p=K O$

The 2015 analysis is especially specific when observing the results of these two financial reports. In that year, there was a theoretical discontinuity between profit and cash flows and 
cash equivalents. The profit was $\$ 7.351$ billion, while the amount of money and cash equivalents was reduced by $\$ 1.499$ billion.

The main reason for this is the high degree of capital intensity that was realized in 2015 .

Investment activities were at an extremely high level, and a large amount of money was used to finance investments. Based on investment activities, a net outflow of $\$ 6.186$ billion was generated. In order to compare the size, the net outflow of money from investment activities covered as much as $84 \%$ of the net profit realized in the observed year. Observing 2015 , the most significant item of outflow of money from investment activities is the capital expenditure item (CAPEX). This involved money funds that are in use with the aim of expanding physical forms of property or fixed assets. With such an investment policy, which is reflected in a high degree of pro-activity, the Coca-Cola Company created an extremely good basis for the future implementation of business operations and allowed conditions for the realization of future profits, which is the basis for generating positive cash flows.

In the following year, 2016, there was a return on investment activity, which can be interpreted by the fact that a part of the investment began to produce a profit. However, what was specific is the fact that CAPEX remained almost at the same level. In the annual period characterized by investment inflows, CAPEX had experienced the relatively low decline of only $11 \%$. This means that Coca-Cola is highly oriented towards the investment business. The breakdown of investment activity from \$6.186 billion in 2015 fell to $\$ 999$ million in 2016.

Looking at the financial statements of Coca-Cola, it can be ascertained that, taking into account its core business which in the cash flow statement and in the income statement is represented through the cash flow from operational activities and the operating profit, it has achieved extremely successful results. From such a position, the fact that a short-term liquidity imbalance can successfully be solved by some types of bank loans ensues, i.e. that there are some objectively healthy conditions for this to occur. If profit from core activities was not realized, the company would not be able to apply for a liquidity loan.

Taking into account the financial activities, the general tendency is that almost all the most successful global companies have negative results in this domain. Coca-Cola joins this group, where it belongs. In 2015 , the dividend paid out amounted to $\$ 5.741$ billion. Also, the company bought its own shares in the amount of $\$ 2,319$ billion. And in this way, Coca-Cola again clearly demonstrates the principles of its business policy that are reflected in its orientation towards capitalization.

Table 2 shows data on the Coca-Cola income statement for 2015 and 2016.

Table 2. The income statement of Coca-Cola for 2015 and 2016. (mil. \$)

\begin{tabular}{|l|l|l|}
\hline Income statement & $\mathbf{2 0 1 6}$ & $\mathbf{2 0 1 5}$ \\
\hline Total income & 41.863 & 44.294 \\
\hline Cost of sold products & 16.465 & 17.482 \\
\hline Gross income & 25.398 & 26.812 \\
\hline Cost of sales and administration & 15.262 & 16.427 \\
\hline Other operative costs & 1.510 & 1.657 \\
\hline Operative profit & 8.626 & 8.728 \\
\hline Interest income & 642 & 613 \\
\hline Interest expenses & 733 & 856 \\
\hline Dividend income & 835 & 489 \\
\hline Other expenditures & 1.234 & 631 \\
\hline Pre-tax profit & 8.136 & 9.605 \\
\hline Income tax & 1.586 & 2.239 \\
\hline Profit after taxation & 6.550 & 7.366 \\
\hline Payments to minority shareholders & 23 & 15 \\
\hline Net profit & $\mathbf{6 . 5 2 7}$ & $\mathbf{7 . 3 5 1}$ \\
\hline
\end{tabular}

Source: https://finance.yahoo.com/quote/KO/financials? $p=K O$ 
Looking at the 2015 cash flow statement, one item is atypical for core business and operational operations. This involves the effects of foreign exchange rate changes. However, since this is a company that is, in the fullest sense, a global one, it is subject to the influence of world movements. The year of 2015 was characterized by an increase in the value of the US dollar, so there is a high degree of possibility that the depreciation of a number of domicile currencies have contributed to the outflow of money.

Looking at 2016, we can also notice a significant paradox in the financial statements, from the aspect of realized profit and cash flow. As far as financial flows are concerned, it can be established that there has been an improvement in the cash flow. Outflows changed their forms and were transformed into inflows - $\$ 1.649$ billion of a negative cash flow in 2015 turned into $\$ 1.246$ billion positive. On the other hand, the net profit fell from $\$ 7.351$ billion to $\$ 6.527$ billion.

The main factor in the decline in net profits, looking at the 2016 income statement, is the decline in the total revenue. An analogy can be seen by analyzing the cash flow statement, as there was decline in inflow from operating activities.

\section{Conclusion}

The preparation and concept of company financial statements entails a legal obligation defined by the normative regulations. In addition to the character of the obligation to be met, financial statements, if they are created according to certain standards, are some kind of mine of information. By proper and adequate analysis, it is possible to establish certain bottlenecks and perform a re-optimization of operations.

One of the important segments is the cash flow statement and the income statement. The main products of the cash flow statement are information relating to items representing the basis by which cash inflows and outflows occur. The income statement represents the financial result of the organization in the form of profit or loss. In contemporary economic circumstances, it is possible to realize certain paradoxical situations. A large number of companies make a profit, that is, a positive financial result, but it entails a significant deficit with regard to fresh money.

Taking into account such a fact, it has also happened that financially profitable companies were brought to the brink of extinction. The main factor in this unnatural situation is the accounting principle represented in the economy.

The fastest short-term solution to similar problems is reflected in the use of bank loans for liquidity. Such loans make sense in those cases where the company achieved a positive financial result from operational activities that relate to the core business of the organization. A fundamental solution to this problem is reflected in the transformation of the basic postulates of business, financial and commercial policies. It is necessary to carry out a thorough analysis of the maturity of the positions of funds and sources of funds and to consider them in a proper manner. Also, it is extremely important to possess concise information on the state of the supplies, so as not to have a worst-case engagement of assets and thus create a liquidity risk.

\section{REFERENCES}

1. Auerbach, A. J., Devereux, M. P. (2013). "Consumption and cash-flow taxes in an international setting." Oxford University Centre for Business Taxation.

2. Delaney, R. P., Nach, R., Epstein, J. B., Weiss Budak, S. (2003). "GAAP: Interpretation and Application of Generally Accepted Accounting Principles”. John Wiley \& Sons Inc.

3. Đukić, T. D. (2005). "Bilans tokova gotovine kao instrument upravljanja likvidnošću preduzeća". Ekonomski fakultet Niš.

4. Epstein, B., Jermakowicz, E. (2007). "Interpretation and Application of International Financial Reporting Standards.” John Wiley \& Sons Inc.

5. Kimmel, P. D., Weygandt, J. J., Kieso, D. E. (2011). "Financial accounting," $6^{\text {th }}$ ed. John Wiley \& Sons Inc.

6. Libby, R., Libby, A. P., Short, D. (2011) "Financial Accounting," Whitby, $7^{\text {th }}$ ed. McGraw-Hill. 
https://finance.yahoo.com/quote/KO/financials?p=KO

\section{Article history:}

- $\quad$ Received 25 October 2017

- Accepted 12 December 2017 